\title{
PHOSPHORUS REQUIREMENT OF TAMBAQUI FINGERLINGS ${ }^{1}$
}

\author{
THALLES JOSÉ REGO SOUSA ${ }^{2 *}$, MARCOS ANTONIO DELMONDES BOMFIM ${ }^{2}$, FELIPE BARBOSA RIBEIRO², \\ SYLVIA SANAE TAKISHITA ${ }^{3}$, DAYANA DA CANCEIÇÃO DA COSTA ${ }^{2}$
}

\begin{abstract}
The objective of this study was to determine the digestible phosphorus requirement in rations for tambaqui fingerlings (Colossoma macropomum). 900 fingerlings $(0.51 \pm 0.06 \mathrm{~g})$ were used in a completely randomized design with six treatments, five replicates, and thirty fish per experimental unit. The treatments consisted of six diets with different digestible phosphorus levels $(0.12,0.33,0.54,0.75,0.95$, and $1.16 \%)$. The fish were fed six times a day, for 63 days. Performance, feed efficiency, and the daily protein, fat, ash, and phosphorus deposition rates of fish were evaluated. The treatments did not influence the feed intake. The elevation of phosphorus levels increased the digestible phosphorus intake linearly, and improved of quadratic form the weight gain, specific growth rate, feed:gain ratio, protein efficiency for weight gain, and daily protein, fat, ash, and phosphorus depositions up to the estimated levels of $0.64,0.66,0.70,0.70,0.62,0.62,0.70$, $0.71 \%$, respectively. The phosphorus efficiency for weight gain worsened with the elevation of phosphorus levels. The recommendation of digestible phosphorus level in rations for tambaqui fingerlings to optimize weight gain and body phosphorus deposition is $0.71 \%$, which corresponds to the estimated level of $1.04 \%$ total phosphorus.
\end{abstract}

Keywords: Initial phase. Minerals. Nutritional requirement.

\section{EXIGÊNCIA DE FÓSFORO PARA ALEVINOS DE TAMBAQUI}

RESUMO - Objetivou-se determinar a exigência de fósforo digestível em rações para alevinos de tambaqui (Colossoma macropomum). Utilizou-se 900 alevinos $(0,51 \pm 0,06 \mathrm{~g})$, em delineamento inteiramente casualizado, com seis tratamentos, cinco repetições, e trinta peixes por unidade experimental. Os tratamentos constituíram-se de seis rações com diferentes níveis de fósforo digestível $(0,12 ; 0,33 ; 0,54 ; 0,75 ; 0,95$; e $1,16 \%)$. Os peixes foram alimentados seis vezes ao dia, durante 63 dias. Avaliaram-se o desempenho, eficiência alimentar e as deposições diárias de proteína, gordura, cinzas e fósforo corporais dos peixes. Os tratamentos não influenciaram no consumo de ração. A elevação dos níveis de fósforo aumentou o consumo de fósforo digestível de forma linear, e melhorou de forma quadrática o ganho de peso, taxa de crescimento específico, conversão alimentar, eficiência proteica para o ganho, e as deposições diárias de proteína, gordura, cinzas e fósforo até os níveis estimados de $0,64 \%, 0,66 \%, 0,70 \%, 0,70 \%, 0,62 \% ; 0,62 \% ; 0,70 \% ; 0,71 \%$, respectivamente. A eficiência de fósforo para o ganho de peso piorou com a elevação dos níveis de fósforo. A recomendação dos níveis de fósforo digestível em rações para alevinos de tambaqui, visando otimizar o desempenho e a deposição corporal de fósforo, é de $0,71 \%$, correspondendo ao nível de $1,04 \%$ de fósforo total.

Palavras-chave: Exigência nutricional. Fase inicial. Minerais.

\footnotetext{
*Corresponding author

${ }^{1}$ Received for publication in $12 / 02 / 2017$; accepted in 05/06/2019.

Paper extracted from the first author's master's dissertation.

${ }^{2}$ Center for Agricultural and Environmental Sciences, Universidade Federal do Maranhão, Chapadinha, MA, Brazil; talesrego@hotmail.com - ORCID: 0000-0003-0051-3722, madbomfim@yahoo.com.br - ORCID: 0000-0002-1707-2970, felipebribeiro@yahoo.com - ORCID: 0000-0002-2505-3964, dayanacosta10@gmail.com - ORCID: 0000-0002-4922-9901.

${ }^{3}$ Faculdade de Tecnologia do Estado de São Paulo, Jacareí, SP, Brazil; sanae.tk@gmail.com - ORCID: 0000-0001-8046-4531.
} 


\section{INTRODUCTION}

Phosphorus is one of the most important minerals in animal nutrition, required by all vertebrates for growth, reproduction, bone formation, and the metabolism of amino acids, carbohydrates and fats (QUINTERO-PINTO et al., 2011; SANTOS, 2012; ARAÚJO et al., 2017). Although fish absorb many essential minerals directly from the aquatic environment, the greater part of the required phosphorus must be obtained in the diet, as the absorption of phosphorous directly from the water is very low, which indicates the need for supplementation of this mineral in the diet (NRC, 2011; BOMFIM, 2013; CHEN et al., 2017).

When the levels of phosphorus in the diet are below the nutritional requirement, the animal's performance is impaired. Inadequate phosphorous intake causes changes in intestinal villi and bone mineralization, and may reduce the amino acid efficiency of body protein deposition in fish and, consequently, increase the discharge of nitrogen to the environment. However, when dietary phosphorus supplementation meets the nutritional requirement, fish show an increase in protein utilization, bone mineralization, and reduction in lipid body deposition (QUINTERO-PINTO et al., 2011; SANTOS, 2012; ZAFAR; KHAN, 2018).

When phosphorus levels in the ration are excessive, the efficiency of its use decreases considerably, increasing its excretion into the environment and contributing to the eutrophication of the aquatic environment. Because of this, it is necessary to adjust the dietary concentration of the element to strictly meet, but not exceed, nutritional requirements (FURUYA et al., 2010; TANG et al., 2012; MUSHARRAF; KHAN, 2019).

Fish ration formulations include phosphorus in different concentrations, forms, and availability or digestibility (QUINTERO-PINTO et al., 2011; SANTOS, 2012). In ingredients of plant origin, 50$80 \%$ of the phosphorus content is associated with phytate, which is unavailable to fish because they lack endogenous phytase production (CAO et al., 2007).

Owing to their productivity and marketability, tambaqui is the most cultivated fish species in the State of Maranhão, with a production of 10,501 thousand tons (11.8\% of national production) in 2017 (IBGE 2019; BUZOLLO et al., 2019). However, there is a lack of information regarding tambaqui nutritional requirements, as highlighted in recent reviews by Dairiki and Silva (2011) and Oliveira, Miranda and Correa (2013). There is a shortage of research papers published in specialized journals regarding the dietary recommendations of phosphorus levels in rations for tambaqui.

Considering the lack of information regarding phosphorus requirements in tambaqui rations and that the dietary requirements of the mineral vary across tambaqui breeding phases, the objective of this study was to determine the requirement of digestible phosphorus in rations for tambaqui (Colossoma macropomum) fingerlings.

\section{MATERIAL AND METHODS}

The experiment was conducted according to the ethical standards of animal research, after being approved by the Ethics Committee on Animal Use of the Federal University of Maranhão (Protocol $\mathrm{N}^{\mathrm{o}}$ : 23115008833/2014-31). The research was carried out in the Food and Nutrition Laboratory of Aquatic Organisms of the Center of Agrarian and Environmental Sciences of the Federal University of Maranhão (UFMA), in Chapadinha, Maranhão, with a duration of 63 days.

900 tambaqui (Colossoma macropomum) fingerlings were used with initial average weights of $0.51 \pm 0.06 \mathrm{~g}$, in a completely randomized design, consisting of six treatments, five replicates, and thirty fish per experimental unit.

The treatments consisted of six isoprotein, isoenergetic, and isocalcium diets, with different digestible phosphorus levels $(0.12,0.33,0.54,0.75$, $0.95,1.16 \%$ ) (Table 1). The digestible phosphorus levels were determined based on the digestibility coefficients of corn, soybean meal and dicalcium phosphate recommended for Nile tilapia by Furuya et al. (2010). The levels of crude protein, methionine plus cystine:lysine, and threonine:lysine were fixed, based on the values recommended by Lima (2013) and Souza (2014) for tambaqui, and by Takishita (2012) for Nile tilapia, respectively. For the other nutritional levels, we used the values recommended for Nile tilapia per NRC (2011).

In the pre-experimental period, which consisted of one week, the fish were stored in the experimental facilities and fed with commercial ration to adapt for the experimental conditions. In the experimental period, the fish were kept in 30 polyethylene boxes (aquarium) with capacity of 500 liters in a closed water circulation system, with a supply system, additional aeration and individual drainage.

The water supply came from artesian well and the cleaning of the boxes was carried out daily by siphoning, always after the water temperature monitoring, which was performed daily at 7:30 and 17:30 hours, with the aid of a mercury bulb thermometer, graduated from 0 to $50^{\circ} \mathrm{C}$. Control of $\mathrm{pH}$, dissolved oxygen content and ammonia in the water were monitored every seven days, using a $\mathrm{pH}$ meter, oximeter and commercial kit for testing ammonia toxicity, respectively. 
T. J. R. SOUSA et al.

Table 1. Percent chemical composition of the experimental rations (natural matter).

\begin{tabular}{|c|c|c|c|c|c|c|}
\hline \multirow{2}{*}{ Ingredients $(\%)$} & \multicolumn{6}{|c|}{ Digestible phosphorus level (\%) } \\
\hline & 0.12 & 0.33 & 0.54 & 0.75 & 0.95 & 1.16 \\
\hline Soybean meal & 66.082 & 66.082 & 66.082 & 66.082 & 66.082 & 66.082 \\
\hline Corn & 19.645 & 19.645 & 19.645 & 19.645 & 19.645 & 19.645 \\
\hline Soy oil & 6.460 & 6.460 & 6.460 & 6.460 & 6.460 & 6.460 \\
\hline Inert & 2.087 & 1.670 & 1.252 & 0.835 & 0.417 & 0.000 \\
\hline L-Lysine-HCl & 0.111 & 0.111 & 0.111 & 0.111 & 0.111 & 0.111 \\
\hline DL-Methionine & 0.266 & 0.266 & 0.266 & 0.266 & 0.266 & 0.266 \\
\hline L-Threonine & 0.405 & 0.405 & 0.405 & 0.405 & 0.405 & 0.405 \\
\hline Limestone & 3.874 & 3.099 & 2.324 & 1.550 & 0.775 & 0.000 \\
\hline Dicalcium phosphate & 0.000 & 1.192 & 2.385 & 3.577 & 4.769 & 5.961 \\
\hline Vitamin and mineral mix ${ }^{1}$ & 0.500 & 0.500 & 0.500 & 0.500 & 0.500 & 0.500 \\
\hline Vitamin $C^{2}$ & 0.050 & 0.050 & 0.050 & 0.050 & 0.050 & 0.050 \\
\hline Salt & 0.500 & 0.500 & 0.500 & 0.500 & 0.500 & 0.500 \\
\hline Antioxidant (BHT) & 0.020 & 0.020 & 0.020 & 0.020 & 0.020 & 0.020 \\
\hline \multicolumn{7}{|c|}{ Calculated composition $^{3}$} \\
\hline Crude protein $(\%)$ & 32.00 & 32.00 & 32.00 & 32.00 & 32.00 & 32.00 \\
\hline Digestible protein $(\%)^{5}$ & 29.34 & 29.34 & 29.34 & 29.34 & 29.34 & 29.34 \\
\hline Digestible energy $\left(\mathrm{Kcal} \mathrm{kg}^{-1}\right)^{5}$ & 3000.00 & 3000.00 & 3000.00 & 3000.00 & 3000.00 & 3000.00 \\
\hline Ether extract $(\%)$ & 8.27 & 8.27 & 8.27 & 8.27 & 8.27 & 8.27 \\
\hline Crude fiber $(\%)$ & 3.84 & 3.84 & 3.84 & 3.84 & 3.84 & 3.84 \\
\hline Total Ca (\%) & 1.62 & 1.62 & 1.62 & 1.62 & 1.62 & 1.62 \\
\hline Total P (\%) & 0.42 & 0.64 & 0.86 & 1.08 & 1.30 & 1.52 \\
\hline Non-phytic P (\%) & 0.16 & 0.38 & 0.60 & 0.82 & 1.04 & 1.26 \\
\hline Digestible P (\%) ${ }^{5}$ & 0.12 & 0.33 & 0.54 & 0.75 & 0.95 & 1.16 \\
\hline Digestible lysine $(\%)^{4}$ & 1.700 & 1.700 & 1.700 & 1.700 & 1.700 & 1.700 \\
\hline Digestible methionine + cystine $(\%)^{4}$ & 1.105 & 1.105 & 1.105 & 1.105 & 1.105 & 1.105 \\
\hline Digestible threonine $(\%)^{4}$ & 1.496 & 1.496 & 1.496 & 1.496 & 1.496 & 1.496 \\
\hline Digestible tryptophan $(\%)^{4}$ & 0.405 & 0.405 & 0.405 & 0.405 & 0.405 & 0.405 \\
\hline
\end{tabular}

${ }^{1}$ Vitamin and mineral mix $\left(5 \mathrm{~kg} \mathrm{t}^{-1}\right)$, with guaranteed levels per kilogram of product: Vit. A, 1,200,000 IU; Vit. D3, 200,000 IU; Vit. E, 1,200 mg; Vit. K3, 2,400 mg; Vit. B1, 4,800 mg; Vit.B2, 4,800 mg; Vit. B6, 4,800 mg; Vit. B12, 4,800 mg; Vit. C, $48.00 \mathrm{mg}$; folic acid, 1,200 mg; Ca pantothenate, 12,000 mg; biotin, $48 \mathrm{mg}$; choline chloride, $108 \mathrm{~g}$; niacin, 24,000 mg; Fe, 50,000 mg; Cu, 3,000 mg; Mn, 20,000 mg; Zn, 30,000 mg; I, 100 mg; Co, 10 mg; Se, 100 mg.

${ }^{2}$ Vit. C: Calcium L-Ascorbic acid 2-monophosphate, $42 \%$ of active ingredient;

${ }^{3}$ Based on the values proposed by ROSTAGNO et al. (2011);

${ }^{4}$ Based on the digestibility coefficients for industrial amino acids proposed by Rostagno et al. (2011);

${ }^{5}$ Based on the digestibility coefficients proposed for Nile tilapia by Furuya et al. (2010).

The ingredients of the experimental rations were mixed, moistened in water heated to approximately $50{ }^{\circ} \mathrm{C}$, and pelletized using a meat grinder. Then the rations were dried, crushed, and sieved to obtain pellets of $3 \mathrm{~mm}$ in diameter.

The rations were offered six times a day $(08: 00,10: 00,12: 00,14: 00,16: 00$, and 18:00 h). At every meal, the rations were offered in small quantities, with successive offerings until apparent satiation, thereby avoiding the over or under delivery of feed.

At the beginning of the experiment, 50 fish were stunned, euthanized in ice water, and frozen. At the end of experiment, after 24-hour fasting, all fish in each tank were weighed, stunned, and euthanized. Subsequently, the final biometry of the fish and the feed consumption per experimental unit were evaluated.

The fish samples (initial and final per experimental plot) were identified, dried in a greenhouse with forced air circulation, predegreased, ground in a ball mill, and packed in containers for further laboratory analysis. The carcasses and rations were analyzed for their composition (moisture, protein, fat, ash, and phosphorus content) according to the procedures described by Detmann et al. (2012). The laboratory analyses were carried out at the Animal Nutrition Laboratories of the Federal University of Maranhão UFMA and Animal Nutrition of the Federal University of Piauí - UFPI.

At the end of the experiment, the following indices of performance and food efficiency were evaluated: feed intake (FI), consumption of digestible phosphorus (CDPH), weight gain (WG), specific growth rate (SGR), feed:gain ratio (FGR), protein efficiency for weight gain (PEWG), and phosphorus efficiency for weight gain (PHEWG). These were calculated according to the following equations: 


$$
\begin{gathered}
\text { FI }(\mathrm{g})=\text { Ration consumed during the experimental period } \\
\operatorname{CDPH}(\mathrm{mg})=\frac{[\text { Feed consumption }(\mathrm{mg}) \times \text { Digestible phosphorus content of the ration }(\%)]}{100} \\
\mathrm{WG}(\mathrm{g})=\text { Final average weight }- \text { Initial average weight } \\
\text { SGR }\left(\% \text { day }^{-1}\right)=\frac{[(\text { Natural logarithm of final weight }(\mathrm{g})-\text { Natural logarithm of initial weight }(\mathrm{g})) \times 100]}{\text { Experimental period (days) }} \\
\text { FGR }\left(\mathrm{g} \mathrm{g}^{-1}\right)=\frac{\text { Feed intake }}{\text { weight gain }} \\
\text { PEWG }\left(\mathrm{g} \mathrm{g}^{-1}\right)=\frac{\text { Weight gain }}{\text { Consumption of crude protein }} \\
\text { PHEWG }\left(\mathrm{g} \mathrm{g}^{-1}\right)=\frac{\text { Weight gain }}{\text { Consumption of phosphorus }}
\end{gathered}
$$

In addition, the rates of the daily body depositions of protein (BDP), fat (BDF), phosphorus $(\mathrm{BDPH})$, and ash (BDA) were calculated according to the methodologies described by Bomfim et al. (2010) and Ribeiro et al. (2006), according to the equations below:

$$
\operatorname{BDP}\left(\mathrm{mg} \mathrm{day}^{-1}\right)=\frac{\{[(\% \text { Final BP } \times \text { final weight, } \mathrm{mg})-(\% \text { Initial BP } \times \text { starting weightl, mg })] / 100\}}{\text { Experimental period (days })}
$$

$\operatorname{BDF}\left(\mathrm{mg} \mathrm{day}^{-1}\right)=\frac{\{[(\% \text { Final body fat } \times \text { final weight }, \mathrm{mg})-(\% \text { Initial body fat } \times \text { starting weightl, } \mathrm{mg})] / 100\}}{\text { Experimental period }(\text { days })}$

$$
\operatorname{BDPH}\left(\mathrm{mg} \mathrm{day}^{-1}\right)=\frac{\{[(\% \text { Final PB } \times \text { final weightl }, \mathrm{mg})-(\% \text { Initial PB } \times \text { starting weightl }, \mathrm{mg})] / 100\}}{\text { Experimental period (days })}
$$

$\operatorname{BDA}\left(\mathrm{mg} \mathrm{day}^{-1}\right)=\frac{\{[(\% \text { Final body ashes } \times \text { final weightl, } \mathrm{mg})-(\% \text { Initial body ashes } \times \text { starting weightl, } \mathrm{mg})] / 100\}}{\text { Experimental period }(\text { days })}$

Statistical analyses were performed using SAS 9.0 software (2002). Data were submitted to analysis of variance at five percent probability level. For the variables that showed significant effects of digestible phosphorus levels by analysis of variance, regression analyses were performed using linear and quadratic models. We also evaluated the discontinuous model "Linear Response Plateau" (LRP). In choosing the best fit model, the value of $P$ (significance) and $R^{2}$ (Sum of squares of the model /Sum of treatment squares) were taken into account.

\section{RESULTS AND DISCUSSION}

During the whole experimental period there was only $1 \%$ mortality, which was not related to the treatments. The maximum and minimum temperatures of the water were $26.5 \pm 0.61{ }^{\circ} \mathrm{C}$ and $24.8 \pm 0.70{ }^{\circ} \mathrm{C}$, respectively. The concentration of dissolved oxygen in the water was $7.35 \pm 0.80 \mathrm{ppm}$,
$\mathrm{pH} 6.0 \pm 0.40$ and total ammonia $\leq 1.00 \mathrm{ppm}$. The physical-chemical parameters of the water were kept within the recommended standards for rearing tambaqui fingerlings throughout the experimental period, as recommended by Gomes et al. (2010) and Mendonça et al. (2012). It was observed that feed intake did not vary $(\mathrm{P}>0.05)$ as a function of treatments. As the feed contained different levels of digestible phosphorus, the digestible phosphorus consumption was influenced $(\mathrm{P}<0.01)$ by the treatments, increasing linearly with the elevation of digestible phosphorus levels in the ration (Tables 2 and 3 ).

Considering that the consumption of ration and, consequently, of energy and other nutrients in the ration did not vary between the evaluated levels, and that the consumption of digestible phosphorus increased linearly with the increase of the content of this mineral in the ration, it can be inferred that the significant effects in other variables evaluated were caused by the difference in consumption of digestible phosphorus. 
Table 2. Feed intake (FI), consumption of digestible phosphorus (CDPH), weight gain (WG), specific growth rate (SGR), feed:gain ratio (FGR), protein efficiency for weight gain (PEWG), and phosphorus efficiency for weight gain (PHEWG) of tambaqui fingerlings and summary analysis of variance, according to the level of digestible phosphorus of the ration.

\begin{tabular}{|c|c|c|c|c|c|c|c|}
\hline \multirow[b]{2}{*}{$\begin{array}{c}\text { Digestible phosphorus level } \\
(\%)\end{array}$} & \multicolumn{7}{|c|}{ Variable } \\
\hline & $\begin{array}{l}\text { FI } \\
(\mathrm{g})\end{array}$ & $\begin{array}{l}\text { CDP } \\
(\mathrm{mg})\end{array}$ & $\begin{array}{l}\text { WG } \\
(\mathrm{g})\end{array}$ & $\begin{array}{c}\text { SGR } \\
\left(\% \text { day }^{-1}\right)\end{array}$ & $\begin{array}{c}\text { FGR } \\
\left(\mathrm{g} \mathrm{g}^{-1}\right)\end{array}$ & $\begin{array}{l}\text { PEWG } \\
\left(\mathrm{g} \mathrm{g}^{-1}\right)\end{array}$ & $\begin{array}{l}\text { PHEWG } \\
\left(\mathrm{g} \mathrm{g}^{-1}\right)\end{array}$ \\
\hline 0.12 & 17.97 & 21.56 & 9.39 & 4.62 & 1.96 & 1.65 & 124.46 \\
\hline 0.33 & 22.63 & 74.68 & 13.54 & 5.28 & 1.71 & 1.95 & 93.48 \\
\hline 0.54 & 18.01 & 97.28 & 13.43 & 5.28 & 1.38 & 2.44 & 86.69 \\
\hline 0.75 & 21.44 & 129.88 & 13.95 & 5.23 & 1.53 & 2.16 & 93.24 \\
\hline 0.95 & 16.41 & 155.90 & 10.99 & 4.98 & 1.53 & 2.13 & 51.51 \\
\hline 1.16 & 18.99 & 207.40 & 10.97 & 4.91 & 1.78 & 1.91 & 36.91 \\
\hline$P>F^{I}$ & 0.9999 & 0.0001 & 0.0098 & 0.0159 & 0.0390 & 0.0636 & 0.0000 \\
\hline$C V(\%)^{2}$ & 29.08 & 27.35 & 23.28 & 8.72 & 26.02 & 28.79 & 27.43 \\
\hline
\end{tabular}

${ }^{1} P>F$ - Significance of F-test for analysis of variance;

${ }^{2} \mathrm{CV}-$ Coefficient of variation.

The effects of dietary phosphorus level variations on fish feed intake do not follow a specific response pattern. The effects observed in this study were similar to those observed by Oliva-Teles and Pimentel-Rodrigues (2004) in studies of European sea bass (Dicentrarchus labrax), which also showed no variation in feed intake between fish fed diets containing $0.48 ; 0.65 ; 0.77 ; 0.86 ; 1.05$ and $1.25 \%$ total phosphorus (DM base). Previously, Pezzato et al. (2006) observed a linear increase in feed intake of tilapia fingerlings as a function of dietary phosphorus supplementation. Furuya et al. (2008) observed a quadratic effect in feed intake as a function of the variation of four levels of available phosphorus $(0.25,0.35,0.45$ and $0.55 \%)$ in the diets of juvenile Nile tilapia.

Regarding weight gain and specific growth rate, the model that best fit the results as a function of the elevation of digestible phosphorus levels was quadratic ( $\mathrm{P}<0.01$ and $\mathrm{P}<0.05$, respectively), which indicated an increase in these variables to the estimated digestible phosphorous level of $0.64 \%$ (Figure 1) and $0.66 \%$, respectively (Tables 2 and 3 ).

Table 3. Adjusted regression equations, determination coefficients, and demand values for the variables weight gain (WG), specific growth rate (SGR), feed:gain ratio (FGR), consumption of digestible phosphorus (CDP), protein efficiency for weight gain (PEWG), and phosphorus efficiency for weight gain (PHEWG) of tambaqui fingerlings according to digestible phosphorus levels $(\mathrm{P})$ of the ration.

\begin{tabular}{|c|c|c|c|c|c|}
\hline Variable & Model & Equation & $\mathrm{P}>\mathrm{F}$ & $\overline{\mathrm{R}^{2}}$ & Requirement (\%) \\
\hline CDP (mg) & Linear & $\mathrm{CDP}=8.03079+165.85 \mathrm{P}$ & 0.0001 & 0.98 & $\begin{array}{ll}---- \\
\end{array}$ \\
\hline WG $(g)$ & Quadratic & $\mathrm{WG}=8.1974+17.131 \mathrm{P}-13,291 \mathrm{P}^{2}$ & 0.0048 & 0.72 & 0.64 \\
\hline WG $(g)$ & LRP & $\mathrm{WG}=12.5432-17.4956(0.5741-\mathrm{P})$ & 0.0087 & 0.48 & 0.57 \\
\hline $\begin{array}{l}\text { FGR } \\
\left(\mathrm{g} \mathrm{g}^{-1}\right)\end{array}$ & Quadratic & $\mathrm{FCR}=2.2093-2.1941 \mathrm{P}+1,5754 \mathrm{P}^{2}$ & 0.0310 & 0.90 & 0.70 \\
\hline $\begin{array}{c}\text { SGR } \\
\left(\% \text { day }^{-1}\right)\end{array}$ & Quadratic & $\mathrm{SGR}=4.4605+2.5269 \mathrm{P}-1.9195 \mathrm{P}^{2}$ & 0.0320 & 0.75 & 0.66 \\
\hline $\begin{array}{c}\text { SGR } \\
\left(\% \text { day }^{-1}\right)\end{array}$ & LRP & $\mathrm{SGR}=5.1328-3.276(0.5778-\mathrm{P})$ & 0.0058 & 0.52 & 0.58 \\
\hline $\begin{array}{l}\text { PEWG } \\
\left(\mathrm{g} \mathrm{g}^{-1}\right)\end{array}$ & Quadratic & $\mathrm{PEWG}=1.3543+2.6857 \mathrm{P}-1.9302 \mathrm{P}^{2}$ & 0.0489 & 0.82 & 0.70 \\
\hline $\begin{array}{l}\text { PHEWG } \\
\left(\mathrm{g} \mathrm{g}^{-1}\right)\end{array}$ & Quadratic & PHEWG $=505.7-946.77 \mathrm{P}+494.98 \mathrm{P}^{2}$ & 0.0001 & 0.89 & ----- \\
\hline
\end{tabular}

The results obtained for the weight gain differ from those observed in studies performed by Miranda et al. (2000) and Ribeiro (2006), who did not find significant variation in the weight gain of Nile tilapia fingerlings when they evaluated phosphorus levels, probably because the observed levels were not limiting. On the other hand, similar effects were reported by Pezzato et al. (2006) when they evaluated five diets with increasing available phosphorus levels $(0.25,0.50,0.75,1.00$, and $1.25 \%$ ) for Nile tilapia (Oreochromis niloticus), by Furuya et al. (2008) when they evaluated the effect of different available phosphorus levels $(0.25,0.35$, 0.45 , and $0.55 \%$ ) for the same species, and by Sousa et al. (2018) when they evaluated different digestible phosphorus levels $(0.27,0.46,0.67,0.91,1.04$, and $1.14 \%$ ) for tambaqui fingerlings.

An increase in weight gain was observed until the estimated digestible phosphorus level reached $0.64 \%$, associated with consumption of similar feed and a linear increase in phosphorus consumption, implying an improvement of feed:gain ratio. This indicates that increased phosphorus in the diet promoted an improvement in the use of nutrients, 
especially for protein deposition, as lean tissue deposition (protein) is more energy efficient than fat deposition because protein incorporates more water in its composition (NOBLET et al., 2001; BOMFIM et al., 2010; SOUSA et al., 2018; MUSHARRAF; KHAN, 2019), thus minimizing the excretion of nitrogenous residues to the environment (BOMFIM 2013).
The elevation of digestible phosphorus levels produced a quadratic effect on feed:gain ratio $(\mathrm{P}<0.05)$ and the protein efficiency of weight gain, increasing these variables until the estimated digestible phosphorus level reached $0.70 \%$. However, the phosphorus efficiency for weight gain decreased $(\mathrm{P}<0.05)$ in a quadratic manner as a result of the increase of this mineral content.

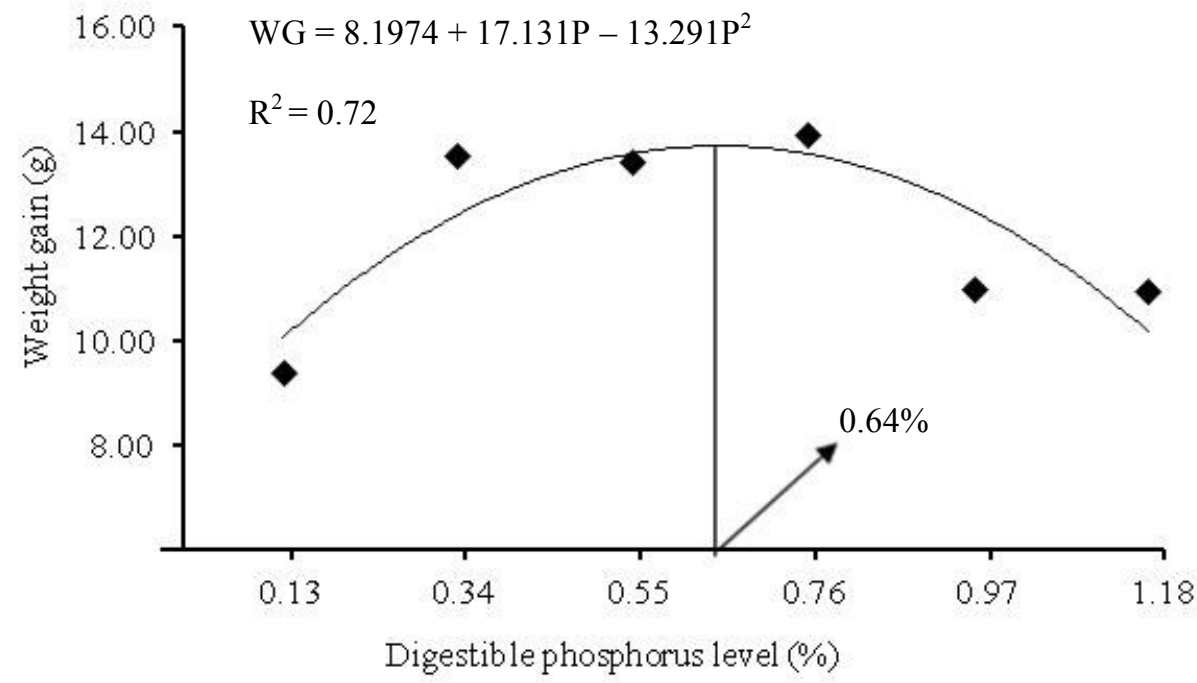

Figure 1. Graphical representation of weight gain for tambaqui fingerlings as a function of digestible phosphorus level of the ration.

Furuya et al. (2008) observed a similar effect on Nile tilapia (35 to $100 \mathrm{~g}$ ) feed:gain ratio when evaluating different available phosphorus levels, estimating the best result for this variable at available phosphorus level of $0.48 \%$. In the same work, the protein efficiency rate had a different effect than was observed in this study, increasing quadratically.

One hypothesis that may explain this reduction in phosphorus efficiency for weight gain is that the increase of phosphorus in the ration causes the absorption efficiency of this mineral to decrease, probably owing to the inactivation of the mechanism for active transport of phosphorus, which increases the fecal loss of potentially digestible phosphorus, as demonstrated by TANG et al. (2012).

The daily body deposition of protein, fat, phosphorus, and ash was influenced quadratically ( $\mathrm{P}<0.05, \mathrm{P}<0.05, \mathrm{P}<0.01, \mathrm{P}<0.05$, respectively) by increased levels of digestible phosphorus, raising these variables until the estimated digestible phosphorous levels of $0.62,0.62,0.71$ (Figure 2), and $0.70 \%$, respectively (Tables 4 and 5).

Table 4. Body deposition of protein (BDP), fat (BDF), phosphorus (BDPH) and ash (BDA) of tambaqui fingerlings according to the digestible phosphorus level of the ration.

\begin{tabular}{ccccc}
\hline $\begin{array}{c}\text { Digestible phosphorus level } \\
(\%)\end{array}$ & $\begin{array}{c}\text { BDP } \\
\left(\mathrm{mg} \mathrm{day}^{-1}\right)\end{array}$ & $\begin{array}{c}\text { BDF } \\
\left(\mathrm{mg} \mathrm{day}^{-1}\right)\end{array}$ & $\begin{array}{c}\text { BDPH } \\
\left(\mathrm{mg} \mathrm{day}^{-1}\right)\end{array}$ & $\begin{array}{c}\text { BDA } \\
(\%)\end{array}$ \\
\hline 0.12 & 22.58 & 9.10 & 0.38 & 3.25 \\
0.33 & 30.94 & 20.27 & 0.77 & 5.84 \\
0.54 & 25.82 & 20.00 & 0.93 & 5.57 \\
0.75 & 31.18 & 15.24 & 0.98 & 5.87 \\
0.95 & 24.84 & 10.52 & 0.66 & 4.59 \\
1.16 & 23.71 & 14.25 & 0.74 & 4.96 \\
\hline$P>F^{1}$ & 0.0653 & 0.0485 & 0.0013 & 0.0356 \\
\hline $\mathrm{CV}(\%)^{2}$ & 24.94 & 43.32 & 31.72 & 26.35 \\
\hline
\end{tabular}

${ }^{1} P>F$ - Significance of F-test for analysis of variance;

${ }^{2} \mathrm{CV}-$ Coefficient of variation. 
Daily phosphorus and ash deposition improved as phosphorus was added to diets. These increases are explained by the fact that phosphorus is an essential component of an animal's body structure. It is essential for the formation of bones (about $37 \%$ of the bone composition corresponds to calcium and $16 \%$ to phosphorus). In addition, it is involved in the formation of cell membranes and phosphoproteins, energy transfer, regulation of acid-base balance, and in enzymatic and hormonal systems involved in amino acid, carbohydrate and fat metabolism, corroborating the improvement in protein deposition rates and fat (BÜNZEN, 2012; SANTOS, 2012; XIE et al., 2017).

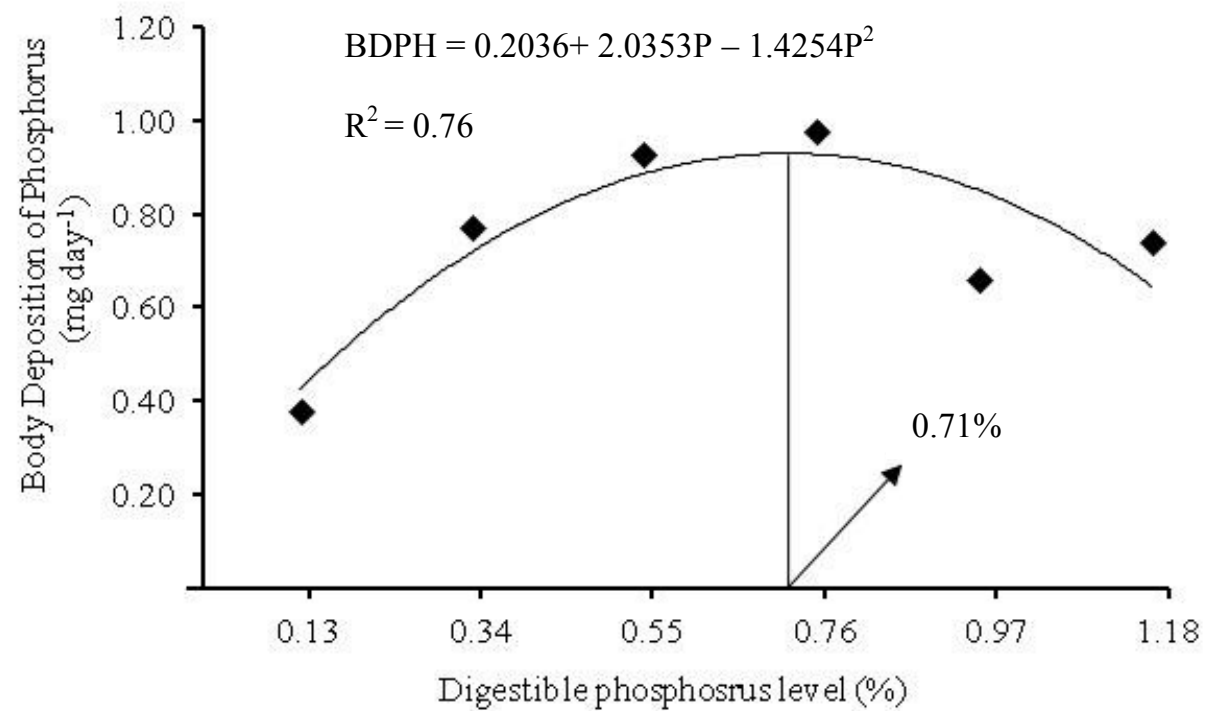

Figure 2. Graphic representation of the daily body phosphorus deposition of tambaqui fingerlings as a function of the digestible phosphorus level of the ration.

A reduction in daily fat deposition was observed with the inclusion of $0.75 \%$ of digestible phosphorus in the ration. The reduction in body fat deposition in fish with increased dietary phosphorus content was also observed by Rocha et al. (2010) in kingfish (Odontesthes argentinensis), by Mai et al. (2006) in yellow croaker (Pseudosciaena crocea) and by Zhang et al. (2006) in Japanese sea bass (Lateolabrax japonicus).

One hypothesis that may explain the reduction in body fat deposition that results from the inclusion of $0.75 \%$ of digestible phosphorus in the diet is that this level of phosphorous favors the energetic metabolism of fatty acids ( $\beta$-oxidation), as phosphorus is the main constituent of the adenosine triphosphate molecule (ATP), which plays an important role in the transfer of energy and in the activation of some regulatory enzymes in this metabolism.

Table 5. Adjusted regression equations, determination coefficients and demand values for the variables of body deposition of protein (BDP), fat (BDF), phosphorus (BDPH) and ash (BDA) of tambaqui fingerlings as a function of digestible phosphorus level $(\mathrm{P})$ of the ration.

\begin{tabular}{cccccc}
\hline Variable & Model & Equation & $\mathrm{P}>\mathrm{F}$ & $\mathrm{R}^{2}$ & Requirement (\%) \\
\hline $\begin{array}{c}\text { BDP } \\
\left(\mathrm{mg} \mathrm{day}^{-1}\right)\end{array}$ & Quadratic & $\mathrm{BDP}=21.025+26.609 \mathrm{P}-21.555 \mathrm{P}^{2}$ & 0.0024 & 0.49 & 0.62 \\
$\begin{array}{c}\mathrm{BDF} \\
\left(\mathrm{mg} \mathrm{day}^{-1}\right)\end{array}$ & Quadratic & $\mathrm{BDF}=-9.1469+28.04 \mathrm{P}-22.774 \mathrm{P}^{2}$ & 0.0396 & 0.34 & 0.62 \\
$\begin{array}{c}\mathrm{BDPH} \\
\left(\mathrm{mg} \mathrm{day}^{-1}\right)\end{array}$ & Quadratic & $\mathrm{BDPH}=0.2036+2.0353 \mathrm{P}-1.4254 \mathrm{P}^{2}$ & 0.0114 & 0.76 & 0.71 \\
$\begin{array}{c}\text { BDA } \\
\left(\mathrm{mg} \mathrm{day}^{-1}\right)\end{array}$ & Quadratic & $\mathrm{BDA}=2.7902+8.6873 \mathrm{P}-6.234 \mathrm{P}^{2}$ & 0.0289 & 0.62 & 0.70 \\
\hline
\end{tabular}

Weight gain has been the main criterion for determining the requirement of a given nutrient by the dose response method (NRC, 2011). To determine the requirement of phosphorus, in addition to weight gain, another parameter that can be used is deposition of body phosphorus (SAKOMURA; ROSTAGNO, 2007; ABIMORAD et al., 2010;
NRC, 2011). In this sense, the recommendation of levels of digestible phosphorus in rations for tambaqui fingerlings that optimizes weight gain and body phosphorus deposition is $0.71 \%$, which corresponds to the estimated level of $1.04 \%$ total phosphorus.

The dietary requirements of phosphorus for 
fish species found in the literature present varied results, some less than that determined in this study, as is the case in Diemer et al. (2014), who recommend $0.60 \%$ total phosphorus for pacu fingerlings, an omnivorous species with morphometric and ecological characteristics similar to tambaqui. Boscolo et al. (2005), recommends $0.75 \%$ total phosphorus, as it provides better performance in bone mineralization and performance of Nile tilapia fingerlings. This variation can be explained by the fact that different species can have distinct digestive systems, physiology, and growth rates (GONÇALVES et al., 2009; BOMFIM et al., 2010; TAKISHITA, 2012).

Optimal nutritional levels similar to those obtained in this study were determined for Nile tilapia fingerlings by Pezzato et al. (2006), in digestible values, and by Ribeiro et al. (2006), in total values, while ARAÚJO et al., (2017) determined similar levels, in digestible values, for tambaqui juveniles.

\section{CONCLUSION}

The recommendation of digestible phosphorus level in rations for tambaqui fingerlings to optimize weight gain and body phosphorus deposition is $0.71 \%$, which corresponds to the estimated level of $1.04 \%$ total phosphorus.

\section{ACKNOWLEDGMENTS}

We would like to thank the Fundação de Amparo à Pesquisa e ao Desenvolvimento Científico e Tecnológico do Maranhão for financing the project.

\section{REFERENCES}

ABIMORAD, E. G. et al. Dietary digestible lysine requirement and essential amino acid to lysine ratio for pacu Piaractus mesopotamicus. Aquaculture Nutrition, v. 16, n. 4, p. 370-377, 2010.

ARAÚJO, J. G. et al. Dietary available phosphorus requeriment for tambaqui, Colossoma macropomum, juveniles based on growth, haematology and bone mineralization. Aquaculture Nutrition, v. 23, n. 5, p. 822-832, 2017.

BOMFIM, M. A. D. et al. Níveis de lisina, com base no conceito de proteína ideal, em rações para alevinos de tilápia-do-Nilo. Revista Brasileira de Zootecnia, v. 39, n. 1, p. 1-8, 2010.

BOMFIM, M. A. D. Estratégias Nutricionais para
Redução das Excreções de Nitrogênio e Fósforo nos Sistemas de Produção de Peixes no Nordeste: Sustentabilidade Ambiental e Aumento da Produtividade. Revista Científica de Produção Animal, v. 15, n. 2, p. 122-140, 2013.

BOSCOLO, W. R. et al. Exigência de fósforo para alevinos de tilápia do Nilo (Oreochromis niloticus). Acta Scientiarum. Animal Sciences, v. 27, n. 1, p. 87-91. 2005.

BÜNZEN, S. et al. Níveis de fósforo digestível para suínos em fase de crescimento. Revista Brasileira Zootecnia, v. 41, n. 2, p. 320-325. 2012.

BUZOLLO, H. et al., Digestible protein requirements and muscle growth in juvenile tambaqui (Colossoma macropomum). Aquaculture Nutrition, v. 25, n. 1, p. 669-679, 2019

CAO, L. et al. Application of microbial phytase in fish feed. Enzyme and Microbial Technology, v. 40, n. 4, p. 497-507, 2007.

CHEN, M. H. et al., Effect of dietary phosphorus levels on growth and body composition of crucian carp, Carassius auratus under indoor and outdoor experiments. Aquaculture Nutrition, v. 23, n. 4, p. 702-709, 2017.

DAIRIKI, J. K.; SILVA, T. B. A. Exigências nutricionais do tambaqui - compilação de trabalhos, formulação de ração adequada e desafios futuros. 1. ed. Manaus: Embrapa Amazônia Ocidental, 2011. 44p (Embrapa Amazônia Ocidental, 91). 2011.

DETMANN, E. et al. Métodos para análise de alimentos. Visconde do Rio Branco, MG: Suprema, p. $214,2012$.

DIEMER, O. et al. Fósforo na alimentação de pacus criados em tanques-rede. Arquivo Brasileiro de Medicina Veterinária e Zootecnia, v. 66, n. 4, p. 1243-1250, 2014.

FURUYA, W. M. et al. Tabelas brasileiras para nutrição de tilápias. 1. ed. Toledo: GFM, 2010. 100 p.

FURUYA, W. M. et al. Exigência de fósforo disponível para tilápia-do-Nilo (35 a 100 g). Revista Brasileira de Zootecnia, v. 37, n. 6, p. 961-966, 2008.

GOMES, L. C. et al. In: Tambaqui (Colossoma macropomum), Espécies nativas para piscicultura no Brasil. 2. ed. Editora UFSM, Santa Maria. 2010. p. $175-204$ 
GONÇALVES, G. S. et al. Relação lisina digestível: proteína digestível em rações para tilápias-do-Nilo. Revista Brasileira de Zootecnia, v. 38, n. 12, p. 2299-2305, 2009.

INSTITUTO BRASILEIRO DE GEOGRAFIA E ESTATÍSTICA - IBGE. Sistema IBGE de Recuperação Automática - SIDRA. MPOG. Disponível em: <http://www.sidra.ibge.gov.br/bda/ tabela/listabl.asp? $\mathrm{c}=3940 \& \mathrm{z}=\mathrm{t} \& \mathrm{o}=21>$. Acesso em: 06 de abr. 2019.

LIMA, C. S. et al. Crude protein levels in the diets of tambaqui, Colossoma macropomum (Cuvier, 1818), fingerlings. Revista Caatinga, v. 29, n. 1, v. 183190, 2016.

MAI, K. et al. Dietary phosphorus requirement of large yellow croaker, Pseudosciaena crocea $R$. Aquaculture, v. 251, n. 2, p. 346-353, 2006.

MENDONÇA, P. P. et al. Efeito da suplementação de fitase na alimentação de juvenis de tambaqui (Colossoma macropomum). Archivos de Zootecnia, v. 61, n. 235 , p. $437-448,2012$.

MIRANDA, E. C. et al. Relação cálcio/fósforo disponível em rações para tilápia do Nilo (Oreochromis niloticus). Revista Brasileira de Zootecnia, v. 29, n. 6, p. 2162-2171, 2000.

MUSHARRAF, M. KHAN, M. A. Dietary Phosphorus Requirement of Fingerling Indian Major Carp, Labeo rohita (Hamilton). Journal of Theworld Aquaculture Society, v. 50, n. 2, p. 469 484, 2019

NATIONAL RESEARCH COUNCIL - NRC. Nutrient requirements of fish and shrimp. Washington: National Academy of Science, 376 p., 2011.

NOBLET, J. Avaliação energética em suínos. In: Workshop Latino-Americano Ajinomoto Biolatina de Nutrição 82 de Aves e Suínos, 2001, Foz do Iguaçu-PR. Anais... Foz do Iguaçu, 2001. p. 2-17.

OLIVA-TELES, O.; PIMENTEL-RODRIGUES, A. M. P. Phosphorus requirements of European sea bass (Dicentrarchus labrax) juveniles. Aquaculture Research, v. 35, n. 7, p. 636-642, 2004.

OLIVEIRA, A. C. B.; MIRANDA, E.; CORREA, R. Exigências nutricionais e alimentação do tambaqui. In: 88 FRACALOSSI, D. M; CYRINO, J. E. P. (Eds.). Nutrição e alimentação de espécies de interesse para a 89 aqüicultura brasileira. Florianópolis - SC: Aquabio, 2013. cap. 11, p. 231 240.
PEZZATO, L. E. et al. Exigência em fósforo disponível para alevinos de tilápia do Nilo. Ciência Rural, v. 36, n. 5, p. 1600-1605, 2006.

QUINTERO-PINTO, L. G. et al. Exigências e disponibilidade de fontes de fósforo para tilápias. Veterinária e Zootecnia, v. 5, n. 2, p. 30-43, 2011.

RIBEIRO, F. B. et al. Níveis de fósforo total em dietas para alevinos de tilápia-do-Nilo. Revista Brasileira de Zootecnia, v. 35, n. 4, p. 1588-1593, 2006.

ROCHA, C. B. et al. Exigência de fósforo disponível para alevinos de peixe-rei (Odonthestes bonariensis) em uma dieta prática. In: XIX Congresso de Iniciação Científica XII Enpos, 2010, Pelotas. Anais... Pelotas. 2010.

ROSTAGNO, R. S. et al. Tabelas brasileiras para aves e suínos - composição de alimentos e exigências nutricionais. 2. ed. Viçosa: Universidade Federal de Viçosa, 2011, 141 p.

SAKOMURA, N. K.; ROSTAGNO, H. S. Métodos de pesquisa em nutrição de monogástricos. Jaboticabal, SP: FUNEP, 2007, 283 p.

SANTOS, J. G. A. Exigência em fósforo digestível para tambaqui (Colossoma macropomum.). 2012. 109 f. Tese (Doutorado em Ciência Animal: Área de Produção Animal) - Universidade Federal de Goiás, Escola de Veterinária e Zootecnia, Goiânia. 2012.

SOUSA, T. J. R. et al., Phosphorus requirements of tambaqui juveniles. Semina Ciências Agrárias, v. 39 , n. 5, p. 2145-2156, 2018.

SOUZA, F. O. Relação da Metionina mais cistina com a lisina em rações para alevinos de tambaqui (Colossoma macromum.). 2014. 49 f. Dissertação (Mestrado em Ciência Anima: Área Nutrição e Alimentação de Animais Monogástricos) Universidade Federal do Maranhão, Chapadinha, 2014

STATISTICAL ANALYSIS SYSTEM - SAS. SAS user's guide: statistics. 5.ed. Cary: SAS Institute, 956 p., 2002.

TAKISHITA, S. S. Relações de treonina e triptofano com a lisina digestível em rações para alevinos de tilápia do Nilo. 2012. 72 f. Tese (Doutorado em Zootecnia: Área de Produção Animal) - Universidade Federal de Viçosa, Viçosa, 2012.

TANG, Q. et al. Dietary Available Phosphorus Affected Growth Performance, Body Composition, and Hepatic Antioxidant Property of Juvenile Yellow 
Catfish Pelteobagrus fulvidraco. The Science World Journal, v. 2012, s/n., p. 1-9, 2012.

XIE, D. et al., Dietary available phosphorus requirement for on growing gibel carp (Carassius auratus gibelio var. CAS III). Aquaculture Nutrition, v. 23, n. 5, p. 1104-1112, 2017.

ZAFAR, N. KHAN, M. Determination of dietary phosphorus requirement of stinging catfish Heteropneustes fossilis based on feed conversion, growth, vertebrae phosphorus, whole body phosphorus, haematology and antioxidant status Aquaculture Nutrition, v. 24, n. 5, p. 1577 1586, 2018.

ZHANG, C. et al. Dietary phosphorus requeriment of juvenile japanese seabass, Lateolabrax japonicus. Aquaculture, v. 255, n. 4, p. 201-209, 2006. 